\title{
Review \\ Metabolic Rewiring and the Characterization of Oncometabolites
}

\author{
Diren Beyoğlu and Jeffrey R. Idle *(i)
}

check for updates

Citation: Beyoğlu, D.; Idle, J.R.

Metabolic Rewiring and the

Characterization of Oncometabolites.

Cancers 2021, 13, 2900. https://doi.

org/10.3390/cancers 13122900

Academic Editors: Giuseppe Broggi and Lucia Salvatorelli

Received: 23 May 2021

Accepted: 8 June 2021

Published: 10 June 2021

Publisher's Note: MDPI stays neutral with regard to jurisdictional claims in published maps and institutional affiliations.

Copyright: (c) 2021 by the authors. Licensee MDPI, Basel, Switzerland. This article is an open access article distributed under the terms and conditions of the Creative Commons Attribution (CC BY) license (https:// creativecommons.org/licenses/by/ $4.0 /)$.
Arthur G. Zupko's Division of Systems Pharmacology and Pharmacogenomics, Arnold and Marie Schwartz College of Pharmacy and Health Sciences, Long Island University, Brooklyn, NY 11201, USA; diren.beyoglu@liu.edu

* Correspondence: jeff.idle@liu.edu; Tel.: +1-718-488-1322

Simple Summary: Oncometabolites are produced by cancer cells and assist the cancer to proliferate and progress. Oncometabolites occur as a result of mutated enzymes in the tumor tissue or due to hypoxia. These processes result in either the abnormal buildup of a normal metabolite or the accumulation of an unusual metabolite. Definition of the metabolic changes that occur due to these processes has been accomplished using metabolomics, which mainly uses mass spectrometry platforms to define the content of small metabolites that occur in cells, tissues, organs and organisms. The four classical oncometabolites are fumarate, succinate, $(2 R)$-hydroxyglutarate and (2S)-hydroxyglutarate, which operate by inhibiting 2-oxoglutarate-dependent enzyme reactions that principally regulate gene expression and response to hypoxia. Metabolomics has also revealed several putative oncometabolites that include lactate, kynurenine, methylglyoxal, sarcosine, glycine, hypotaurine and $(2 R, 3 S)$-dihydroxybutanoate. Metabolomics will continue to be critical for understanding the metabolic rewiring involving oncometabolite production that underpins many cancer phenotypes.

Abstract: The study of low-molecular-weight metabolites that exist in cells and organisms is known as metabolomics and is often conducted using mass spectrometry laboratory platforms. Definition of oncometabolites in the context of the metabolic phenotype of cancer cells has been accomplished through metabolomics. Oncometabolites result from mutations in cancer cell genes or from hypoxiadriven enzyme promiscuity. As a result, normal metabolites accumulate in cancer cells to unusually high concentrations or, alternatively, unusual metabolites are produced. The typical oncometabolites fumarate, succinate, $(2 R)$-hydroxyglutarate and (2S)-hydroxyglutarate inhibit 2-oxoglutaratedependent dioxygenases, such as histone demethylases and HIF prolyl-4-hydroxylases, together with DNA cytosine demethylases. As a result of the cancer cell acquiring this new metabolic phenotype, major changes in gene transcription occur and the modification of the epigenetic landscape of the cell promotes proliferation and progression of cancers. Stabilization of HIF1 $\alpha$ through inhibition of HIF prolyl-4-hydroxylases by oncometabolites such as fumarate and succinate leads to a pseudohypoxic state that promotes inflammation, angiogenesis and metastasis. Metabolomics has additionally been employed to define the metabolic phenotype of cancer cells and patient biofluids in the search for cancer biomarkers. These efforts have led to the uncovering of the putative oncometabolites sarcosine, glycine, lactate, kynurenine, methylglyoxal, hypotaurine and $(2 R, 3 S)$-dihydroxybutanoate, for which further research is required.

Keywords: oncometabolite; metabolomics; fumarate; succinate; (2R)-hydroxyglutarate; (2S)-hydroxyglutarate; hypoxia; histone demethylation; DNA demethylation

\section{Introduction}

The description of the structure of DNA reported by Watson and Crick in 1953 [1,2] and the discovery of cellular oncogenes by Varmus and Bishop in 1976 [3] not only led to the award of the Nobel Prize to each of these scientists, but also had a secondary 
and little discussed impact on cancer biology. These monumental research milestones deviated cancer research away from small molecules to the macromolecular and genetic level. Up until these turning points, there had been considerable research activity into the role that cancer has on cellular metabolism and the effects of cellular metabolism of environmental chemicals on cancer causation. After Watson and Crick, the field of biochemistry underwent a transformation away from intermediary metabolism, swiftly culminating in the discovery of tRNA [4], mRNA [5,6] and ribosomes [7]. The pioneering work of Otto Warburg in the 1920s on altered metabolic pathways in cancer cells was largely to remain unrecognized for 80 years. Following the oncogene discovery, the role of chemical metabolism in carcinogenesis was gradually to be eclipsed by oncogenes, tumor suppressor genes and cell signaling. As Weinberg [8] put it, "The virologists [were] emboldened by the discovery of new animal cancer viruses and their new theories ... those who had spent their lives researching chemical carcinogens became increasingly demoralized, seeing no clear way to advance their work". Fortuitously, today, cell metabolism has returned to the center stage in cancer research. As Wishart has asked, is cancer a genetic disease or a metabolic disease? He argues that decades of cancer analysis have uncovered nearly 1000 known cancer-associated genes ( 250 oncogenes and $\sim 700$ tumor suppressor genes) and that typically two mutations in each of these genes would lead to $>1$ million cancer genotypes, making the genetic fingerprinting of cancers for personalized oncology a formidable task [9]. On a more optimistic note, he continues that most oncogenes and tumor suppressors play fundamental roles in cellular metabolism involving a limited number of pathways. He concludes that while "cancer as a genetic disease looks to be impossibly complex, cancer as a metabolic disease appears to be remarkably simple" [9].

When Hanahan and Weinberg introduced their six hallmarks of cancer two decades ago [10], cancers were seen as having six essential alterations in cell physiology that collectively dictated malignant growth. These were self-sufficiency in growth signals, insensitivity to growth-inhibitory signals, evasion of programmed cell death (apoptosis), limitless replicative potential, sustained angiogenesis and tissue invasion and metastasis. There was no mention of metabolism. Their second rendering of Hallmarks of Cancer [11] acknowledged that the preceding decade had introduced reprogramming of energy metabolism as an emerging hallmark. There was now a recognition that activated oncogenes such as RAS and MYC and mutant tumor suppressors like TP53 were involved in a switch away from mitochondrial oxidative phosphorylation to cytosolic glycolysis. This rewiring of energy metabolism was first observed as a characteristic of cancer by Otto Warburg in the 1920s [12,13] and is now widely known as "the Warburg effect". The aerobic glycolytic process produces an approximately 18-fold lower amount of ATP but permits the rechanneling of glycolytic intermediates into biosynthetic pathways that produce amino acids, nucleosides and other building blocks required for cell division. Certain cancer-associated mutations can therefore enable cancer cells to metabolize nutrients in a way that supports proliferation rather than efficient energy production [14]. The terminal metabolite in glycolysis is lactate, which is secreted by the cancer cells. Interestingly, a subpopulation of cancer cells has been described that use the lactate produced by neighboring cells as their principal energy source [15].

The repurposing of cellular energy metabolism is by no means the only metabolic trait that cancers can express. Another metabolic idiosyncrasy that cancer cells use to their advantage is the production of so-called oncometabolites. Perusal of the literature reveals that there is no agreed concept of an oncometabolite. Many definitions are very precise and refer to the structurally similar metabolites arising from the tricarboxylic acid (TCA) cycle in cancer cells and that promote tumorigenesis and progression through similar epigenetic mechanisms. The four examples given were (2R)-hydroxyglutarate (D-2-hydroxyglutarate), (2S)-hydroxyglutarate (L-2-hydroxyglutarate), succinate and fumarate [16-18]. Gene mutations related to the TCA cycle enzymes fumarate hydratase $(\mathrm{FH})$, succinate dehydrogenase (SDH) and isocitrate dehydrogenase (IDH) were variously discovered in cancer cells. This led to a new paradigm of oncometabolite-driven tumori- 
genesis, whereby mitochondrial metabolites accumulated in certain cancers and acted as oncogenic signaling molecules [19]. Some authors considered such metabolites as "bona fide oncometabolites" [19]. These oncometabolites bear a close structural similarity to another TCA cycle metabolite, 2-oxoglutarate (2-OG; 2-ketoglutarate, $\alpha$-ketoglutarate) and inhibit the pleiotropic actions of 2-OG on gene regulation (Figure 1), which is an obligate cofactor in HIF prolyl hydroxylase (HPH), histone demethylation by JHDM enzymes (lysine demethylases (Jumonji C domain-containing histone demethylases)) and in demethylation of 5-methylcytosine by TET (ten-eleven translocation) dioxygenases. The oncometabolites shown in Figure 1 prevent demethylation of both histones and DNA and therefore alter the epigenetic landscape promoting tumorigenesis $[17,19,20]$. Other authors advanced a more generalized characterization, that of significant alterations in cellular metabolism arising from cancer-associated gene mutations [21].

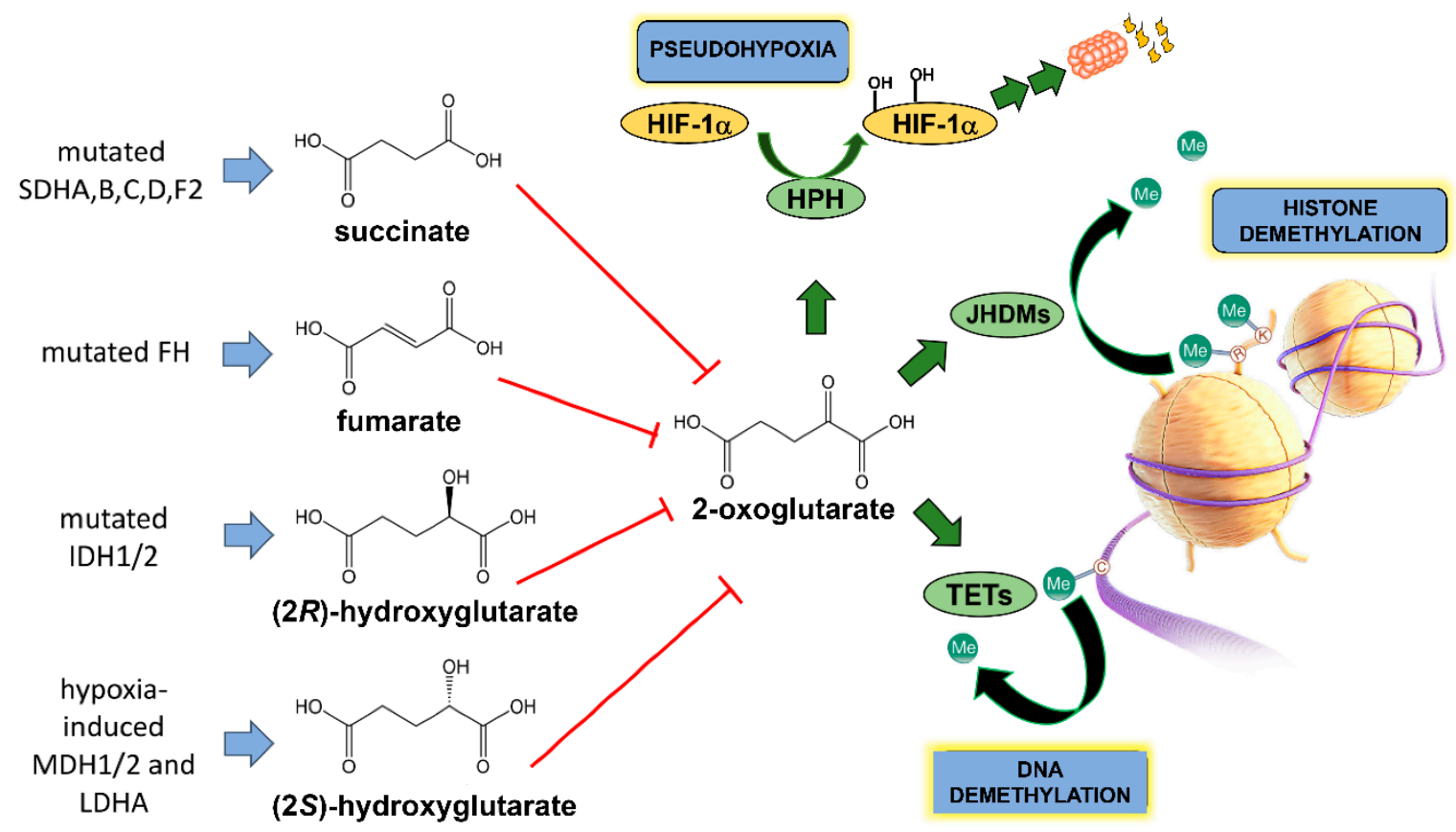

Figure 1. Origin of the four TCA cycle-related oncometabolites and their structural similarity to 2-oxoglutarate. SDHA/B/C/D/F2 represent succinate dehydrogenase complex subunits A-D and succinate dehydrogenase complex assembly factor 2; FH represents fumarate dehydratase; IDH1/2 represent isocitrate dehydrogenase 1 and 2; MDH1/2 represent malate dehydrogenase 1 and 2; LDHA represents lactate dehydrogenase A. HPH is HIF prolyl hydroxylase that leads to HIF- $1 \alpha$ proteasomal degradation, JHDMs are lysine demethylases (Jumonji C domain-containing histone demethylases) and TETs are ten-eleven translocation (TET) methylcytosine dioxygenases.

In this review, we will also examine the evidence for the existence of other oncometabolites that are unrelated to the processes depicted in Figure 1. Importantly, we will describe how the tools of metabolomics have been employed to search for oncometabolites arising from perturbations of cancer cell metabolism.

\section{Metabolomics}

There are several reports on the background of metabolomics [22] and its use in biomarker definition $[23,24]$ and the discovery of elucidation of biochemical networks and mechanisms [25]. There has also been an almost 40-fold (on average) increase per annum of reports on metabolomics cited in PubMed over the past 20 years, attesting to the explosive emergence of this field. As has been pointed out, despite the early and disparate definitions of both metabolomics [26,27] and metabonomics [28], the latter term today usually refers to studies conducted using nuclear magnetic resonance spectroscopy (NMR), whereas the former term encompasses both NMR and mass spectrometry (MS), together 
with other technologies $[22,24]$. A working definition of metabolomics would be that previously reported [22,24], "metabolomics studies the low molecular weight metabolites [e.g., $<1.5 \mathrm{kDa}$ ] found in cells and organisms, usually through the analysis of plasma/serum, urine or cell culture medium using mainly MS or NMR technologies." The different ways in which metabolomic investigations can be conducted has been discussed in detail by us and others $[23,24]$. One analytical method ideal for the separation, detection and quantitation of small molecular intermediates, such as the known oncometabolites succinate, fumarate and 2-hydroxyglutarate, is gas chromatography-mass spectrometry (GC-MS). Liquid chromatography-based methodologies, such as ultraperformance chromatography coupled with time-of-flight or Orbitrap mass spectrometry, are most commonly used in metabolomic investigations. They have the important benefits of simple or no sample preparation, high throughput and generated features (mass/charge ratios $(\mathrm{m} / \mathrm{z}$ )/ retention times (RT)) that run into thousands per sample analyzed, especially when the instruments are operated in both the positive and negative ion electrospray modes. That notwithstanding, translating thousands of ions that can comprise multiple types of adducts and front-end fragment ions into molecular candidates based upon $\mathrm{m} / \mathrm{z}$ and RT values is not always straightforward, especially in the case of isomers. GC-MS, on the other hand, despite reduced throughput and yield of features, coupled with a need to derivatize samples to render the analytes volatile, produces diagnostic mass spectra. These spectra are generated, say, $5 / \mathrm{s}$ by electron ionization (EI) at $70 \mathrm{eV}$, conditions that permit comparison with standardized libraries of spectra for the purpose of compound identification. The current NIST/EPA/NIH EI-MS library contains over 350,000 spectra. We adopted a GC-MS metabolomic workflow to interrogate the small intermediary metabolite component of the plasma [29-33], urine [30], liver [31,34] and cultured cell [35,36] metabolomes. Others have utilized gas chromatography coupled to a time-of-flight mass spectrometer (GC-TOFMS) in cancer research [37]. It is worth noting that GC-MS methodologies were employed in the earliest metabolomics investigations, which sought to characterize the chemical composition of leaf extracts from Arabidopsis thaliana [27,38]. Regarding LC-MS methodologies, a large number of diverse protocols has been published for both targeted [39] and untargeted [40] approaches.

\section{TCA Cycle Oncometabolites-Role of Metabolomics}

\subsection{Fumarate}

The fumarate hydratase gene (FH) was discovered to bear an N64T mutation in an individual with a Leydig cell tumor who was part of a kindred with hereditary leiomyomatosis and renal cell cancer (HLRCC). Based on the study of other tumors, the authors concluded that some Leydig cell tumors are caused by germline FH mutations [41]. A similar situation was reported for dominantly inherited uterine fibroids, skin leiomyomata and papillary renal cell cancer with various FH mutations [42]. Using pulmonary adenocarcinoma A549 cells, FH mutation was mimicked by knockdown of FH mRNA with siRNA.

Intracellular levels of fumarate, succinate, lactate and glucose were monitored using targeted metabolomics by means of NMR. These experiments doubled the intracellular fumarate concentration, with no change in succinate but dramatic elevations in both glucose and lactate, showing that knockdown of FH was sufficient to upregulate glycolysis [43]. However, in kidney cells derived from mice in which the Fh1 gene had been disrupted, fumarate levels rose by over 100-fold compared with kidney cells from wildtype mice. In these investigations, TCA metabolites were monitored by targeted GC-MS metabolomics, both with and without addition of either $\left[{ }^{13} \mathrm{C}\right]$ glucose or $\left[{ }^{13} \mathrm{C}\right]$ glutamine [44]. Targeted GC-MS metabolomics was also employed to analyze TCA cycle metabolites in HLRCC and other tumor samples [45]. Elevated fumarate in tumors as a result of $F H$ inactivation was reported to lead to stabilization of hypoxia-inducible factors (HIFs). Under conditions of normoxia, HIFs are subject to proteasomal degradation by a mechanism involving proline 4-hydroxylation of HIFs by HIF prolyl hydroxylase. Fumarate competes with the HIF prolyl hydroxylase co-substrate 2-OG causing HIF upregulation [46] (see Figure 1). 
Fumarate-mediated HIF upregulation coupled with adaptation to glycolysis (see above) leads to an environment permissive for tumorigenesis [43]. This state has been termed pseudohypoxia [47] as it resembles the effects of hypoxia on HIF upregulation and tumorigenesis. It is now believed to be an extensive and cooperative network involving HIFs, mitochondrial metabolism and the Warburg effect [48]. The FH gene has been characterized as both a "housekeeping gene par excellence" and a tumor suppressor gene [42].

Elevated cellular fumarate due to mutated $F H$ has an additional metabolic consequence known as "succination". Nucleophiles, in particular thiol groups, can add across the double bond of fumarate by the Michael addition leading to a succinate residue attached to the protein (Figure 2). Succination can have profound biological effects. For example, succination of two cysteine residues in KEAP1 results in the activation of transcription factor NRF2, which results in the transcription of genes involved in the antioxidant response [49]. It has been suggested that the cellular protective properties of NRF2 may be hijacked by cancer cells to promote cancer growth [50]. Aconitase is another TCA cycle enzyme that converts citrate stereospecifically to isocitrate. Aconitase can be succinated in FH-deficient cells through three iron/sulfur-binding cysteine residues leading to impaired aconitase activity [49]. Therefore, there are multiple metabolic effects of $F H$ mutations in tumor cells, but unfortunately no untargeted metabolomics investigation appears to have been reported. The presence of succinated proteins in tumors with FH mutations has been detected using immunohistochemistry [51]. Other succinate-containing metabolites that were dysregulated in uterine leiomyomas with mutated $F H$ were detected by LC-MS metabolomics. Specifically, $\mathrm{N}^{6}$-succinyladenosine and argininosuccinate were reported [52]. While it is attractive to imagine that both of these elevated metabolites were the result of the Michael addition of fumarate to the nucleophilic nitrogen atoms of adenosine and arginine, the authors advanced alternative hypotheses concerning fumarate metabolism [52].

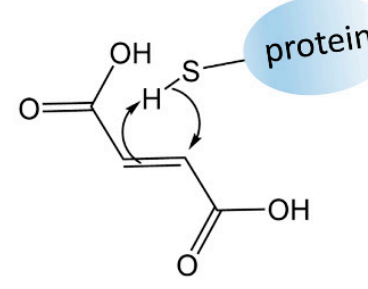

fumarate

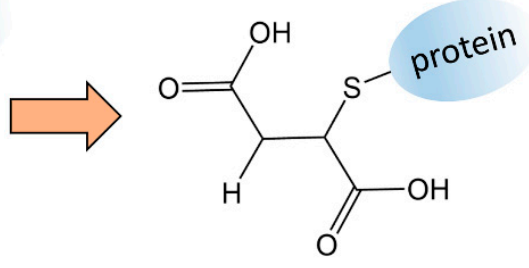

2-(S-succino)cysteine residue

Figure 2. Reaction of protein thiols with elevated cellular fumarate by the Michael addition leading to succinated proteins.

\subsection{Succinate}

In the TCA cycle, succinate dehydrogenase (SDH) converts succinate to fumarate, which is further metabolized by $\mathrm{FH}$ to malate. SDH is heterotetrameric and comprises four subunits (A to D) and is the only enzyme that participates in both the TCA cycle and the respiratory electron transfer chain. The flavoprotein SDHA and iron-sulfur protein SDHB are the two catalytic subunits. SDHC and SDHD are hydrophobic membrane-anchoring subunits that are involved in binding ubiquinone in the respiratory chain. The SDHD gene $(S D H D)$ was reported to bear germline mutations in hereditary paraganglioma [53]. Concurrently, SDHC mutations were shown to be a cause of autosomal dominant paraganglioma type 3 [54]. Subsequently, SDHA [55] and SDHB [56] mutations were said to cause pheochromocytoma and paraganglioma. Finally, SDHAF2, a gene that plays an essential role in the assembly of SDH and the flavination of the SDHA subunit, was found to be mutated in familial and sporadic paraganglioma and pheochromocytoma $[57,58]$.

The SDH enzyme of the yeast Saccharomyces cerevisiae is structurally and functionally similar to its mammalian counterpart. The effects on the yeast metabolome of tumorigenic mutations in both human SDHC (SDH3) and SDHD (SDH4) modelled into the S. cerevisiae 
genome were explored using ${ }^{1} \mathrm{H}$ NMR-based metabolomics, referred to by the authors as "metabolic footprinting" [59]. Regarding SDHC mutations, Arg47Lys, Arg47Cys, Arg47Glu and SDHC knockout (KO) had variable metabolic effects, with relatively small changes in amino acid uptake by cells relative to the wildtype (WT) but greater changes in the release of non-amino acid metabolites by mutated yeast cells into the medium relative to the WT. For example, in SDHC-mutated yeast, the release of succinate was $200 \%$ of the WT, of fumarate $\sim 50 \%$ of the WT. For SDHD-mutated yeast cells (Asp88Glu, Asp88Asn, Asp88Lys) and SDHD KO cells, the succinate and fumarate changes were less dramatic, but isobutyrate secretion was less pronounced for the KO than the WT [59]. Unfortunately, ${ }^{1} \mathrm{H}$ NMR suffers from decreased sensitivity and resolution compared to mass spectrometric methodologies and it was difficult to make either a quantitative or statistical evaluation of the published data.

\section{3. (2R)-Hydroxyglutarate}

The sequencing of 13,023 genes in human breast and colorectal cancers uncovered a number of genes that were mutated at a significant frequency and that were mostly not known to be genetically altered in tumors [60]. Subsequently, this analysis was extended to the most common and lethal type of brain tumor, glioblastoma multiforme (GMB), with the sequencing of 20,661 genes. The isocitrate dehydrogenase 1 gene IDH1 was reported to be mutated in a large number of young patients and in most patients with secondary GMB [61]. In the discovery screen, IDH1 was mutated in five of 22 GBM tumors. Interestingly, all five had the same heterozygous point mutation leading to R132H. This R132 residue was known to bind isocitrate in the enzyme's active site. The further functional significance of mutated IDH1 was not known at that time. However, an untargeted metabolomic study using LC-MS was conducted that compared glioblastoma cells that were either WT for IDH1 or with the R132H, R132C, R132L or R132S mutations. Metabolomic analysis showed that IDH1-mutated cells had acquired a novel metabolic ability-the synthesis of (2R)-hydroxyglutarate (D-2-hydroxyglutarate; 2R-HG) by NADPH-dependent reduction of 2-OG [62]. Surprisingly, 2R-HG accumulated in mutant cells to a concentration of 5-35 mM. This change in metabolic activity of the R132H enzyme from oxidative decarboxylation of isocitrate to 2-OG into dehydrogenation of 2-OG to $2 \mathrm{R}-\mathrm{HG}$ was rationalized by structural analysis of the enzyme's active site [62]. In summary, tumor DNA sequencing led to the discovery of $I D H$ mutations in GMB, but it was metabolomics that led to the functional significance of these mutations.

Mutations of IDH1 were found in 188 acute myeloid leukemia (AML) samples, specifically, R132C, R132H and R132S. No R132 mutations were detected in IDH2 [63]. It was subsequently reported that elevated concentrations of 2R-HG in AML were associated with either IDH1 mutations or the R140Q mutation of the mitochondrial homolog IDH2. The common feature of these mutations not shared by WT cells was the production of 2R-HG. These investigators used targeted metabolic profiling by GC-MS to establish the production of $2 \mathrm{R}-\mathrm{HG}$ by human embryonic kidney cells transfected with mutant IDH R172K [64]. Mutation of IDH1 or IDH2 leading to production of 2R-HG was referred to as "neomorphic enzyme activity" by these authors [64]. LC-MS-based metabolomic profiling showed that 2R-HG levels in AML cells harboring the IDH1 R132 mutation and in serum from these patients was 50-fold higher than in WT AML [65]. Although 2R-HG appears to accumulate in cancer cells, which helps drive their proliferation, there has been a report that background physiological levels of 2R-HG can facilitate proliferation of primary fibroblasts [66]. The question has been posed, is IDH a tumor suppressor or an oncogene? The congruence of mutations in both IDH1 and IDH2 that target arginine residues involved in the binding of isocitrate together with the retention of one WT allele (no loss of heterozygosity) strongly suggests that these are oncogenes [67]. This definition would also fit an assignment of an oncometabolite for 2R-HG [62]. Mutation of IDH1 and IDH2 therefore represents a loss of function with respect to isocitrate metabolism and a gain of function regarding 2-OG metabolism. Mutation is not believed to occur for IDH3. 
Both IDH2 and IDH3 are found in mitochondria where they execute the canonical reaction of isocitrate to 2-OG in the TCA cycle. IDH1, on the other hand, functions in the cytoplasm and peroxisomes.

The unifying property of the three oncometabolites, succinate, fumarate and (2R)hydroxyglutarate, is their ability to inhibit a class of enzymes called 2-oxoglutaratedependent dioxygenases that function to regulate the transcription factor HIF- $1 \alpha$, histone demethylases and TET 5-methylcytosine hydroxylases (Figure 1).

\section{4. (2S)-Hydroxyglutarate}

Using both GC-MS and RFIC-MS (ion chromatography-MS), a metabolomics investigation of clear cell renal cell carcinoma (ccRCC), the most common kidney cancer histologic subtype, established more than 10-fold elevation of (2S)-hydroxyglutarate (L-2hydroxyglutarate; $2 \mathrm{~S}-\mathrm{HG}$ ) in tumor tissue relative to normal renal parenchyma, $2 \mathrm{~S}-\mathrm{HG}$ levels were greater than those of 2R-HG. Transformed cell lines of renal origin also displayed higher 2S-HG than 2R-HG [68]. These metabolomic findings led to mechanistic investigations to uncover the source of the elevated 2S-HG. An inborn error of metabolism due to loss-of-function mutations in L-2-hydroxyglutarate dehydrogenase (L2HGDH), which converts 2S-HG to 2-OG, was known to lead to urinary excretion of 2S-HG [69]. The mRNA and protein expression of L2HGDH was investigated and found to be attenuated in ccRCC. Elevated 2S-HG was also associated with impaired formation of 5-hydroxymethylcytosine (5hmC) by TET1 and TET2 [68]. Therefore, 2S-HG has similar effects on 2-oxoglutaratedependent dioxygenases as 2R-HG (Figure 1). While low levels of L2HGDH in ccRCC tumors could explain the accumulation of $2 \mathrm{~S}-\mathrm{HG}$, the question remained regarding the metabolic origin of 2S-HG. Malate dehydrogenases 1 and 2 (MDH1/2; Figure 1) were known to convert 2-OG to 2S-HG in an "off-target" reaction [70]. However, it was not known if MDH1 and 2 produced the 2S-HG observed in ccRCC tumors. However, this group subsequently reported that $2 \mathrm{~S}-\mathrm{HG}$ production from 2-OG by malate dehydrogenase was an adaption to hypoxia; 2S-HG inhibited electron transport and glycolysis to offset mitochondrial reductive stress caused by hypoxia [71].

The first link between an oncogene and specific metabolite production was the demonstration that lactate dehydrogenase A (LDHA) was the target of the protooncogene MYC. Increased LDHA was required for growth of both human and rat transformed cellular spheroids that have a hypoxic inner environment [72]. Although the production of lactate was increased in their experiments, the authors did not investigate the role of lactate per se in promoting anchorage-independent growth. The increase in lactate was taken as a sign of the Warburg effect [72]. However, under conditions of hypoxia, it was reported that LDHA could reduce $2-\mathrm{OG}$ to selectively produce $2 \mathrm{~S}-\mathrm{HG}$ [73].

In the case of $2 \mathrm{~S}-\mathrm{HG}$, this oncometabolite was discovered by metabolomic analysis of tumor versus unaffected tissue. This subsequently led to a better biochemical and molecular understanding of tumorigenesis. These reports demonstrate the growing interaction between intermediary metabolism and DNA biology.

\section{Nontraditional Oncometabolites-The Role of Metabolomics}

\subsection{Sarcosine}

The point has been made that while gene and protein expression have been extensively profiled in human cancers, little is known about alterations to the metabolome that characterize cancer progression [74]. Using GC-MS and LC-MS untargeted metabolomics methodologies, 1126 metabolites were profiled in 262 clinical samples related to prostate cancer. Urinary sarcosine ( $N$-methylglycine) was identified as a differential metabolite that increased during prostate cancer progression to metastasis. Although various further investigations [75-77] linked the presence of sarcosine to prostate cancer invasion, migration and aggressiveness, a definitive mechanism for the role of sarcosine in prostate cancer was not apparent [74]. In a subsequent study, it was reported that urinary sarcosine, after a rectal digital examination, could not distinguish prostate cancer patients from those with 
no evidence of malignancy. Sarcosine could not be considered as a differential metabolite for prostate cancer stage, grade or aggressiveness [78-80]. Others also made similar conclusions regarding serum sarcosine [81]. Urinary sarcosine also failed to distinguish between prostate cancer and benign prostate hypertrophy patients together with healthy men [82]. As for the detection of prostate cancer, it was reported that the diagnostic power of sarcosine was not better than that of prostate cancer antigen PCA3 in serum or urine [83]. In contrast to early reports, a Norwegian study of 3000 prostate cancer cases and 3000 controls found that men with a high serum sarcosine concentration were at a modestly reduced prostate cancer risk [84]. Considering the most recent evaluations of sarcosine [85,86], it is best considered as a biomarker for prostate cancer, especially when combined with other biomarkers such as prostate-specific antigen (PSA). According to these findings, sarcosine does not appear to possess the hallmarks of an oncometabolite. However, a study in which human prostatic cell lines were incubated with sarcosine demonstrated that the methyl donor S-adenosylmethionine (SAM) was elevated, together with increases in methylation of CpG islands only in prostatic cell lines but not cell lines of nonprostate origin [87]. This report showed for the first time that sarcosine is an epigenetic modifier of prostate cells, which may contribute to its function as an oncometabolite.

\subsection{Glycine}

Using untargeted LC-MS/MS metabolomics on the NCI-60 cancer cell lines, the consumption and release of 219 metabolites from the media were profiled. Glycine consumption and the manifestation of glycine synthesis in mitochondria correlated with cancer cell proliferation rates. The unexpected finding that rapidly proliferating cancer cells had an increased reliance on glycine metabolism was not reproduced in rapidly proliferating nontransformed cells. It was postulated that glycine may be used for de novo purine nucleotide biosynthesis or that one-carbon groups derived from glycine may be used in cellular methylation reactions [88]. Moreover, glycine is part of the serine-glycine onecarbon pathway that is involved in the synthesis of the purines and pyrimidines necessary for rapid cell proliferation. In addition, methylation of DNA and histones (Figure 1) that regulate the epigenetic landscape of the cell requires the cofactor SAM. Following methyl transfer from SAM, the serine-glycine one-carbon pathway is necessary for the resynthesis of methionine [89]. Together with glutamine, a principal fuel of cancer cells [90], glycine, serine and methionine are obligatory fuels for these pathways. Of these, only methionine is an essential amino acid and therefore to satisfy its need for this amino acid, the cancer cell must obtain it from the extracellular environment. All four amino acids are imported to the cancer cell via the upregulated transporters SLC6A14 and SLC38A5 [89].

Tumor initiation cells in non-small cell lung cancer (NSCLC) were reported by transcriptomic analysis to possess highly elevated expression of glycine decarboxylase (GLDC), which was found to induce striking changes in glycolysis and glycine/serine metabolism. This led the authors to describe GLDC as an oncogene. Furthermore, GLDC metabolic activity was required for its tumorigenic function [91]. LC-MS-based metabolomics was used to profile HLF and 3T3 cells overexpressing GLDC, in addition to A549 lung adenocarcinoma cells with retroviral knockdown of GLDC. Glycolytic intermediates glucose 1-phosphate and phosphoenolpyruvate, together with the pyrimidines thymidine, deoxyuridine, thymine, cytosine and uracil, were all upregulated in the HLF and 3T3 cells. In particular, pyruvate, thymidine and thymine were downregulated in the A549 cells with GLDC knockdown. Supplementation with sarcosine increased proliferation of A549 cells with GLDC knockdown [91]. 
Although glycine is not a TCA cycle intermediate, it bears some of the characteristics of an oncometabolite. Specifically, it seems to be produced enzymically in cancer cells and it appears to promote cancer cell proliferation. However, a clear relationship between these two characteristics is lacking. Future research may establish glycine as a bona fide oncometabolite.

\subsection{Hypotaurine}

Using capillary electrophoresis-mass spectrometry (CE-MS), 247 metabolites were measured, of which 16 were statistically significantly decreased and four increased in GBM relative to grossly normal surrounding brain tissue. When compared across tumor grades II to IV, hypotaurine had the strongest correlation with tumor grade. Homocysteic acid (HCA), an inhibitor of cysteine sulfinic acid (CSA) decarboxylase (EC 4.1.1.29) that produces hypotaurine from cysteinesulfinate, caused arrest of U-251 glioblastoma cells [92]. Using GC-MS profiling, CSA was reported to have a $>23$-fold level in glioblastomas compared with grade 2 gliomas $[93,94]$. As shown in Figure 1, 2-OG is the oxygen donor for the hydroxylation of HIF-1 $\alpha$. It was reported that hypotaurine diminished levels of hydroxylated HIF- $1 \alpha$ in U-251 cells by inhibition of HIF prolyl hydroxylase in a concentration-dependent manner, showing that hypoxia signaling was activated by hypotaurine. It was also reported that taurine could suppress the formation of hypotaurine. When given in their drinking water to mice bearing xenotransplanted glioblastomas, taurine produced a marked growth delay of transplanted tumors [92]. The second enzyme system that can produce hypotaurine is (2-aminoethanethiol) dioxygenase (ADO; EC 1.13.11.19), which synthesizes hypotaurine from cysteamine [95]. Using CE-MS, it was reported that hypotaurine is one of the top-ranked metabolites that could distinguish glioblastomas from low-grade gliomas. There was also a strong association between expression levels of $\mathrm{ADO}$ and hypotaurine concentrations in tumors [92]. A recent study was reported in which ADO was abrogated using CRISPR/Cas9-mediated gene editing. This limited the proliferation of glioblastoma cells in vitro and tumor growth in vivo in a mouse model [96]. These findings strongly support the role of hypotaurine as an oncometabolite in glioblastoma and point to potential druggable targets for this tumor.

\subsection{Lactate}

Most cancer cells augment glucose and glutamine consumption to fulfill their need for rapid proliferation. In doing so, energy metabolism is deregulated away from mitochondrial oxidation of pyruvate in favor of glycolysis, the end product of which is lactate that is actively exported from the cancer cell [97]. Until comparatively recently, lactate was considered to be mere "metabolic junk". Recently, it has been recognized that lactate that is discarded by hypoxic cancer cells and cancer-associated fibroblasts can be utilized as a fuel by well-oxygenated cancer cells that are close to blood vessels. This metabolic symbiosis is essential for the progression of fast-growing tumors $[97,98]$. This participation of lactate in cancer-cancer and cancer-stroma shuttles was foreshadowed by the work from 35 years ago that first described the "lactate shuttle" in relation to exercise $[99,100]$. Lactate has now been characterized as a "signaling oncometabolite" [101]. Lactate is sensed by the G protein-coupled receptor Gpr132 of macrophages leading to cancer cell adhesion, migration and invasion correlating with metastasis and poor prognosis in breast cancer [102]. Competition for nutrients between cancer cells and immune cells, such as tumor-associated macrophages (TAMs), arises due to hypoxic regions within the tumor. Oncometabolites such as lactate, but also succinate and 2-HG, interact with TAMs to alter their phenotype and enhance tumor progression [103]. 
The question is, what role has metabolomics played in establishing lactate as an oncometabolite? In a report of $2-\mathrm{HG}$ quantitation in human gliomas using high-field ${ }^{1} \mathrm{H}$ MRS, lactate was found to be elevated fivefold in the IDH1R132H and IDH2R172K mutant brain tumor tissue compared with healthy brain tissue [104]. This association with 2-HG in mutated glioma was not in itself evidence that lactate was an oncometabolite, but provided a promising sign. Lactate has been described as a cancer-associated metabolite biomarker in colorectal cancer [105] and thyroid cancer [106]. High-resolution magic-angle spinning ${ }^{1} \mathrm{H}$ NMR has been employed in a metabolomics investigation of malignant thyroid tissue [107] and of prostate cancer [108], and in both cases lactate was the predominant biomarker.

In summary, several reports have established a role and a mechanism for lactate as an oncometabolite. The production of lactate by tumors was first observed by Warburg [12,13] but its characterisation as an oncometabolite has been aided by its detection in several types of cancer by metabolomics.

\subsection{Kynurenine}

Kynurenine is a metabolite of the essential amino acid tryptophan (and the least abundant amino acid in most proteins). As a consequence, most cellular tryptophan is converted to serotonin or to kynurenine, the latter long known to be the starting point of the pathway leading to de novo nicotinic acid and NAD synthesis [109]. It has been reported that the oncogenic transcription factor MYC mediates enhanced expression of the tryptophan importers SLC1A5 and SLC7A5 together with the enzyme AFMID that synthesizes kynurenine from $N$-formylkynurenine [110]. By activating the transcription factor AHR, kynurenine regulates growth promoting genes in cancer cells [111]. Interestingly, increased flux through the kynurenine pathways will lead to elevated nicotinic acid. NADH and NADPH [112] have recently been reported as being overexpressed in tumor cells with mutant p53 [113].

Kynurenine appears to be a good candidate for an oncometabolite. Moreover, the discovery of enhanced tryptophan cellular uptake and metabolism in the kynurenine pathway was established using UPLC-TQMS metabolomics [110].

\subsection{Methylglyoxal}

One of the consequences of the Warburg effect is that augmented cellular glycolytic flux can lead to increased formation of methylglyoxal (MGO), a principal precursor of advanced glycation end products (AGEs). As a result, enhanced protein glycation may contribute to a number of pathologies, including cancer [114]. MGO irreversibly modifies an estimated 1 to $5 \%$ of proteins at arginine residues, forming the MGO-derived argpyrimidine [115] and hydroimidazolone [116] AGEs. The accumulated evidence suggests that MGO-modified proteins connect diabetes with cancer [117] and are associated with several cancers [118]. By silencing the detoxication of MGO by glyoxalase 1, it was reported that MGO favored nuclear localization of the transcriptional coactivator YAP (Yes-associated protein) [119] and inactivation of the Hippo tumor suppressor pathway [120] in breast cancer cells, thereby promoting proliferation [121]. A metabolomic investigation has been reported in which HeLa cervical cancer cells were profiled by LC-MS at different phases of the cell cycle, and 921 metabolites were detected. The authors stated that MGO in particular was found to oscillate in concentration according to the phase of the cell cycle, with higher concentrations in $\mathrm{G}_{1}$ than in $\mathrm{SG}_{2} \mathrm{M}$ [122]. It had earlier been reported that $\mathrm{MGO}$ activated the checkpoint kinases Chk1 and Chk2 in an AGE-dependent manner in human embryonic kidney HEK 293 cells [123].

The potential role of MGO as an oncometabolite appears to involve the formation of AGEs and deserves further investigation. 


\subsection{Miscellaneous}

One example of a putative oncometabolite based upon a single study is $(2 R, 3 S)$ dihydroxybutanoic acid (2,3-DHBA). A GC-MS-based metabolomics investigation into AML patients with and without IDH1 and IDH2 mutations was reported. As expected, 2-HG was highly statistically significantly elevated in plasma of patients with IDH1R132 and IDH2R140 neomorphic enzymes. Unexpectedly, another plasma metabolite, 2,3-DHBA, was similarly elevated and highly correlated with plasma 2-HG levels. When ROC analysis was conducted, 2,3-DHBA was a superior biomarker ( $80 \%$ specificity; $87.3 \%$ sensitivity) for IDH1/2 mutation in AML compared to the oncometabolite 2-HG (80\% specificity; $63.8 \%$ sensitivity) [33].

It has been proposed that 2,3-DHBA is synthesized by mutant IDH1 and IDH2 similarly to the synthesis of $2 \mathrm{R}-\mathrm{HG}$ from 2-OG. Moreover, we have also suggested that the precursor of 2,3-DHBA in this reaction is (3S)-hydroxy-2-oxobutanoate formed by the transamination of the amino acid L-threonine (Figure 3) [33]. The properties of 2,3-DHBA with respect to cancer cell proliferation and its epigenetic regulation are yet to be established.

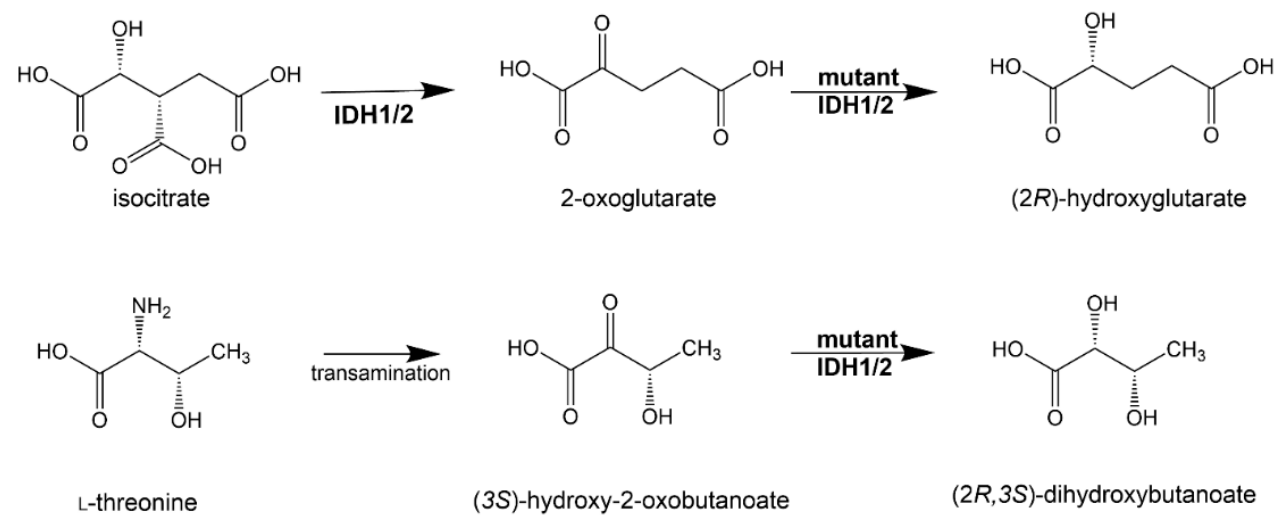

Figure 3. Structural relationship between the putative oncometabolite $(2 R, 3 S)$-dihydroxybutanoate, oncometabolite $(2 R)$ hydroxyglutarate, isocitrate and 2-oxoglutarate.

A few reports have nominated oncometabolites that are supported by little evidence. In discussing the role of a diet, gut microbiota and metabolism on the incidence of colorectal carcinoma, digestion of dietary red meat and the metabolism of primary bile acids by the gut microbiota were said to produce hydrogen sulfide (H2S) and secondary bile acids, such as deoxycholic acid (DCA). H2S and DCA were characterized as oncometabolites in colorectal carcinoma [124]. Published metabolomic data were reviewed for investigations into thyroid cancer, whereby cancerous cells had been compared to their "counterpart noncancerous cells". Metabolites that differed between these two sets of samples were characterized by these authors as "oncometabolites", suggesting that metabolites found more commonly in cancer cells are oncometabolites [106], an interpretation with which we would disagree. The authors relied on the report of David Wishart et al. [105] who, in addition to the oncometabolites discussed above, listed asparagine (leukemia), choline (prostate, brain, breast cancer) and polyamines (most cancers). The principal criterion for inclusion in their list was "endogenous metabolites that either initiate or sustain tumor growth and metastasis".

Table 1 lists the known and putative oncometabolites whose characteristics have been defined by metabolomics. 
Table 1. Known and putative oncometabolites defined by metabolomics.

\begin{tabular}{|c|c|c|c|c|}
\hline Oncometabolite & Tumors & Metabolomic Contribution & $\begin{array}{l}\text { Strength of } \\
\text { Evidence }\end{array}$ & Reference \\
\hline Fumarate & HLRCC & $\begin{array}{l}\text { Linked } F H \text { mutation to TCA and glycolytic } \\
\text { metabolites }\end{array}$ & +++ & [43-45] \\
\hline Succinate & $\begin{array}{c}\text { Hereditary } \\
\text { paraganglioma } \\
\text { Pheochromocytoma }\end{array}$ & $\begin{array}{l}\text { Linked } S D H \text { mutations to succinate and } \\
\text { other metabolites }\end{array}$ & +++ & [59] \\
\hline $\begin{array}{l}(2 R)- \\
\text { Hydroxyglutarate }\end{array}$ & $\begin{array}{l}\text { Glioblastoma multiforme } \\
\text { Acute myeloid leukemia }\end{array}$ & Linked $I D H 1$ and $I D H 2$ mutations to $2 \mathrm{R}-\mathrm{HG}$ & +++ & {$[33,62,64,65]$} \\
\hline $\begin{array}{c}(2 S)- \\
\text { Hydroxyglutarate }\end{array}$ & Clear cell RCC & $\begin{array}{l}\text { Linked L2HGDH activity in tumors to } \\
\text { 2S-HG }\end{array}$ & +++ & {$[68]$} \\
\hline Lactate & Several cancers & $\begin{array}{l}\text { Signaling molecule contributing to } \\
\text { proliferation, migration, invasion, } \\
\text { angiogenesis, immune system escape and } \\
\text { resistance to therapy }\end{array}$ & +++ & {$[97,101,125,126]$} \\
\hline Kynurenine & Colon cancer & $\begin{array}{l}\text { Activation of transcription factor AHR that } \\
\text { regulates growth-promoting genes }\end{array}$ & + & {$[110,111]$} \\
\hline Methylglyoxal & $\begin{array}{l}\text { Breast and colorectal } \\
\text { cancer }\end{array}$ & $\begin{array}{l}\text { AKT activation through } \mathrm{PI} 3 \mathrm{~K} / \mathrm{mTORC} 2 \text { and } \\
\text { Hsp27 regulation }\end{array}$ & + & {$[118,127]$} \\
\hline Sarcosine & Prostate cancer & $\begin{array}{l}\text { Variable reports of linkage of sarcosine to } \\
\text { prostate cancer; no clear mechanism; } \\
\text { potential biomarker }\end{array}$ & \pm & [74-86] \\
\hline Glycine & NCI-60 cell lines & $\begin{array}{l}\text { Linked glycine metabolism to rapidly } \\
\text { proliferating cancer cells; postulated } \\
\text { mechanism involving glycine decarboxylase } \\
\text { (GLDC); cells overexpressing GLDC } \rightarrow \\
\uparrow \text { glycolytic intermediates and } \uparrow \text { pyrimidines }\end{array}$ & + & {$[88,91]$} \\
\hline Hypotaurine & Glioblastoma multiforme & $\begin{array}{l}\text { Established role for hypotaurine in } \\
\text { glioblastoma multiforme; correlative and } \\
\text { mechanistic data point to hypotaurine as an } \\
\text { oncometabolite }\end{array}$ & ++ & [92] \\
\hline $\begin{array}{l}(2 R, 3 S)- \\
\text { Dihydroxybutanoate }\end{array}$ & Acute myeloid leukemia & $\begin{array}{c}\text { Found in plasmas of mutant IDH1/2, } \\
\text { 2,3-DHBA is greater than WT IDH1/2 and } \\
\text { strongly correlated with } 2 \mathrm{R}-\mathrm{HG} ; 2,3-\mathrm{DHBA} \\
\text { is a better biomarker for mutated IDH than } \\
\text { classical oncometabolite } 2 \mathrm{R}-\mathrm{HG}\end{array}$ & \pm & [33] \\
\hline
\end{tabular}

,+++++ , and + indicate strength of evidence that is high, intermediate or low, respectively. \pm indicates strength of evidence that is currently equivocal.

\section{Rewiring Cancer Metabolism as a Therapeutic Strategy}

Ninety years ago, Warburg found that cancer relies on unusual metabolic pathways to fuel its rapid growth $[12,13]$. This concept was adopted by Agios Pharmaceuticals when they began to research IDH mutations in glioma and AML [128] and then reported that cancer-associated IDH1 mutations produced 2R-HG, which they identified as an oncometabolite [62]. Agios developed a first-in-class drug AG-221 (enasidenib) that specifically targeted AML harboring oncogenic IDH2 mutations [129]. Enasidenib was granted regulatory approval by the FDA on 1 August 2017 for the treatment of adult patients with relapsed or refractory acute myeloid leukemia with an isocitrate dehydrogenase-2 (IDH2) mutation as detected by an FDA-approved test [130]. The efficacy of the drug is based upon inhibition of the gain of function associated with production of 2R-HG by cancer cells. Decreasing levels of the oncometabolite attenuated the epigenetic dysregulation and removed the block on cellular differentiation [129]. While a typical cancer cell is replete 
with mutations, no other gain-of-function mutations that lead to oncometabolites have so far been described [130].

In the case of succinate and fumarate, there have been drugs developed in relation to SDH and FH. However, a metabolomic screen of hPheo1 pheochromocytoma cells and SDHB knockdown hPheo1 cells together with cancer tissues with and without SDHx mutations revealed that the polyamines spermidine and spermine were significantly elevated in relation to mutated succinate dehydrogenase. Accordingly, polyamine pathway inhibitors inhibited the growth of hPheo1 cells in vitro as well as mouse xenografts [131]. These findings open up a new therapeutic avenue for pheochromocytomas bearing SDHx mutations. However, they are not based upon rewiring of an oncometabolite pathway.

\section{Conclusions}

Mutations in oncogenes and tumor suppressor genes were long believed to initiate the principal pathways to tumorigenesis. Nevertheless, a supplementary pathway exists that involves the metabolic reprogramming of cancer cells. Mutations that lead to inactivated enzymes involved in intermediary metabolism can cause cellular accumulation of small molecules that trigger or amplify oncogenic pathways. Such small molecules are now known as oncometabolites. The link between cancer mutations and the cancer cell metabolic phenotype has been studied extensively using metabolomics. Mutations in fumarate hydratase, succinate dehydrogenase and isocitrate dehydrogenase together with hypoxia-driven promiscuous substrate usage by both lactate dehydrogenase A and malate dehydrogenase 2 lead to the formation of oncometabolites. As a result, the modified metabolic phenotypes can drive cancer cell proliferation and progression. Metabolomic investigation of cancer metabolic phenotypes has led to the understanding that cancer cell accumulation of the oncometabolites fumarate, succinate, (2R)-hydroxyglutarate or (2S)hydroxyglutarate propels tumorigenesis. The affected pathways largely involve TCA cycle metabolites. There is a second group of metabolites involved in amino acid metabolism, which can best be described as putative oncometabolites. These include sarcosine, glycine, hypotaurine and $(2 R, 3 S)$-dihydroxybutanoate. Further research is required to establish these as oncometabolites. Metabolomic analysis has been central to the discovery and definition of both the established and putative oncometabolites. Metabolic rewiring of cancer cells permits them to escape from housekeeping metabolic duties and switch to the synthesis of metabolic building blocks required for proliferation. There is only one known example of a gain-of-function mutation unique to cancer tissues and this has impeded the development of drugs that can oppose the effects of oncometabolites without affecting healthy cells. It is nevertheless clear that metabolomics will continue to play a significant role in the study of cancer.

Author Contributions: Both authors contributed to the writing, review and editing of the manuscript. Both authors have read and agreed to the published version of the manuscript.

Funding: This research received no external funding.

Conflicts of Interest: The authors declare no conflict of interest.

\section{References}

1. Watson, J.D.; Crick, F.H. Genetical implications of the structure of deoxyribonucleic acid. Nature 1953, 171, 964-967. [CrossRef]

2. Watson, J.D.; Crick, F.H. Molecular structure of nucleic acids; a structure for deoxyribose nucleic acid. Nature 1953, 171, 737-738. [CrossRef] [PubMed]

3. Stehelin, D.; Varmus, H.E.; Bishop, J.M.; Vogt, P.K. DNA related to the transforming gene(s) of avian sarcoma viruses is present in normal avian DNA. Nature 1976, 260, 170-173. [CrossRef] [PubMed]

4. Hoagland, M.B.; Stephenson, M.L.; Scott, J.F.; Hecht, L.I.; Zamecnik, P.C. A soluble ribonucleic acid intermediate in protein synthesis. J. Biol. Chem. 1958, 231, 241-257. [CrossRef]

5. Volkin, E.; Astrachan, L. Phosphorus incorporation in Escherichia coli ribo-nucleic acid after infection with bacteriophage T2. Virology 1956, 2, 149-161. [CrossRef]

6. Volkin, E. The Function of Rna in T2-Infected Bacteria. Proc. Natl. Acad. Sci. USA 1960, 46, 1336-1349. [CrossRef] [PubMed]

7. Palade, G.E. A small particulate component of the cytoplasm. J. Biophys. Biochem. Cytol. 1955, 1, 59-68. [CrossRef] 
8. Weinberg, R.A. Racing to the Beginning of the Road. The Search for the Origin of Cancer; W.H. Freeman and Company: New York, NY, USA, 1996; p. 274.

9. Wishart, D.S. Is Cancer a Genetic Disease or a Metabolic Disease? EBioMedicine 2015, 2, 478-479. [CrossRef]

10. Hanahan, D.; Weinberg, R.A. The hallmarks of cancer. Cell 2000, 100, 57-70. [CrossRef]

11. Hanahan, D.; Weinberg, R.A. Hallmarks of cancer: The next generation. Cell 2011, 144, 646-674. [CrossRef]

12. Warburg, O.; Posener, K.; Negelein, E. Ueber den Stoffwechsel der Tumoren. Biochem. Z. 1924, 152, 319-344.

13. Warburg, O.; Wind, F.; Negelein, E. The Metabolism of Tumors in the Body. J. Gen. Physiol. 1927, 8, 519-530. [CrossRef] [PubMed]

14. Vander Heiden, M.G.; Cantley, L.C.; Thompson, C.B. Understanding the Warburg effect: The metabolic requirements of cell proliferation. Science 2009, 324, 1029-1033. [CrossRef] [PubMed]

15. Kennedy, K.M.; Dewhirst, M.W. Tumor metabolism of lactate: The influence and therapeutic potential for MCT and CD147 regulation. Future Oncol. 2010, 6, 127-148. [CrossRef] [PubMed]

16. Collins, R.R.J.; Patel, K.; Putnam, W.C.; Kapur, P.; Rakheja, D. Oncometabolites: A New Paradigm for Oncology, Metabolism, and the Clinical Laboratory. Clin. Chem. 2017, 63, 1812-1820. [CrossRef]

17. Morin, A.; Letouze, E.; Gimenez-Roqueplo, A.P.; Favier, J. Oncometabolites-driven tumorigenesis: From genetics to targeted therapy. Int. J. Cancer 2014, 135, 2237-2248. [CrossRef]

18. Xiang, K.; Jendrossek, V.; Matschke, J. Oncometabolites and the response to radiotherapy. Radiat. Oncol. 2020, 15, 197. [CrossRef]

19. Sciacovelli, M.; Frezza, C. Oncometabolites: Unconventional triggers of oncogenic signalling cascades. Free Radic. Biol. Med. 2016, 100, 175-181. [CrossRef]

20. Zdzisinska, B.; Zurek, A.; Kandefer-Szerszen, M. Alpha-Ketoglutarate as a Molecule with Pleiotropic Activity: Well-Known and Novel Possibilities of Therapeutic Use. Arch. Immunol. Ther. Exp. 2017, 65, 21-36. [CrossRef]

21. Yang, M.; Soga, T.; Pollard, P.J. Oncometabolites: Linking altered metabolism with cancer. J. Clin. Investig. 2013, 123, 3652-3658. [CrossRef]

22. Beyoglu, D.; Zhou, Y.; Chen, C.; Idle, J.R. Mass isotopomer-guided decluttering of metabolomic data to visualize endogenous biomarkers of drug toxicity. Biochem. Pharmacol. 2018, 156, 491-500. [CrossRef] [PubMed]

23. Sinclair, K.; Dudley, E. Metabolomics and Biomarker Discovery. Adv. Exp. Med. Biol. 2019, 1140, 613-633. [CrossRef]

24. Beyoglu, D.; Idle, J.R. Metabolomic and Lipidomic Biomarkers for Premalignant Liver Disease Diagnosis and Therapy. Metabolites 2020, 10, 50. [CrossRef]

25. Johnson, C.H.; Ivanisevic, J.; Siuzdak, G. Metabolomics: Beyond biomarkers and towards mechanisms. Nat. Rev. Mol. Cell Biol. 2016, 17, 451-459. [CrossRef] [PubMed]

26. Tweeddale, H.; Notley-McRobb, L.; Ferenci, T. Effect of slow growth on metabolism of Escherichia coli, as revealed by global metabolite pool ("metabolome") analysis. J. Bacteriol. 1998, 180, 5109-5116. [CrossRef]

27. Fiehn, O. Metabolomics-the link between genotypes and phenotypes. Plant. Mol. Biol 2002, 48, 155-171. [CrossRef] [PubMed]

28. Nicholson, J.K.; Lindon, J.C.; Holmes, E. 'Metabonomics' Understanding the metabolic responses of living systems to pathophysiological stimuli via multivariate statistical analysis of biological NMR spectroscopic data. Xenobiotica 1999, 29, 1181-1189. [CrossRef]

29. Fahrner, R.; Beyoglu, D.; Beldi, G.; Idle, J.R. Metabolomic markers for intestinal ischemia in a mouse model. J. Surg. Res. 2012, 178, 879-887. [CrossRef]

30. Semmo, N.; Weber, T.; Idle, J.R.; Beyoglu, D. Metabolomics reveals that aldose reductase activity due to AKR1B10 is upregulated in hepatitis C virus infection. J. Viral. Hepat. 2015, 22, 617-624. [CrossRef]

31. Patel, D.P.; Krausz, K.W.; Xie, C.; Beyoglu, D.; Gonzalez, F.J.; Idle, J.R. Metabolic profiling by gas chromatography-mass spectrometry of energy metabolism in high-fat diet-fed obese mice. PLoS ONE 2017, 12, e0177953. [CrossRef]

32. Simillion, C.; Semmo, N.; Idle, J.R.; Beyoglu, D. Robust Regression Analysis of GCMS Data Reveals Differential Rewiring of Metabolic Networks in Hepatitis B and C Patients. Metabolites 2017, 7, 51. [CrossRef] [PubMed]

33. Idle, J.R.; Seipel, K.; Bacher, U.; Pabst, T.; Beyoglu, D. (2R,3S)-Dihydroxybutanoic Acid Synthesis as a Novel Metabolic Function of Mutant Isocitrate Dehydrogenase 1 and 2 in Acute Myeloid Leukemia. Cancers 2020, 12, 2842. [CrossRef]

34. Beyoglu, D.; Imbeaud, S.; Maurhofer, O.; Bioulac-Sage, P.; Zucman-Rossi, J.; Dufour, J.F.; Idle, J.R. Tissue metabolomics of hepatocellular carcinoma: Tumor energy metabolism and the role of transcriptomic classification. Hepatology 2013, 58, 229-238. [CrossRef]

35. Wang, M.; Keogh, A.; Treves, S.; Idle, J.R.; Beyoglu, D. The metabolomic profile of gamma-irradiated human hepatoma and muscle cells reveals metabolic changes consistent with the Warburg effect. PeerJ 2016, 4, e1624. [CrossRef]

36. Keogh, A.; Senkardes, S.; Idle, J.R.; Kucukguzel, S.G.; Beyoglu, D. A Novel Anti-Hepatitis C Virus and Antiproliferative Agent Alters Metabolic Networks in HepG2 and Hep3B Cells. Metabolites 2017, 7, 23. [CrossRef]

37. Denkert, C.; Budczies, J.; Kind, T.; Weichert, W.; Tablack, P.; Sehouli, J.; Niesporek, S.; Konsgen, D.; Dietel, M.; Fiehn, O. Mass spectrometry-based metabolic profiling reveals different metabolite patterns in invasive ovarian carcinomas and ovarian borderline tumors. Cancer Res. 2006, 66, 10795-10804. [CrossRef] [PubMed]

38. Fiehn, O.; Kopka, J.; Dormann, P.; Altmann, T.; Trethewey, R.N.; Willmitzer, L. Metabolite profiling for plant functional genomics. Nat. Biotechnol. 2000, 18, 1157-1161. [CrossRef] [PubMed] 
39. Zullig, T.; Zandl-Lang, M.; Trotzmuller, M.; Hartler, J.; Plecko, B.; Kofeler, H.C. A Metabolomics Workflow for Analyzing Complex Biological Samples Using a Combined Method of Untargeted and Target-List Based Approaches. Metabolites 2020, $10,342$. [CrossRef]

40. Pezzatti, J.; Boccard, J.; Codesido, S.; Gagnebin, Y.; Joshi, A.; Picard, D.; Gonzalez-Ruiz, V.; Rudaz, S. Implementation of liquid chromatography-high resolution mass spectrometry methods for untargeted metabolomic analyses of biological samples: A tutorial. Anal. Chim. Acta 2020, 1105, 28-44. [CrossRef]

41. Carvajal-Carmona, L.G.; Alam, N.A.; Pollard, P.J.; Jones, A.M.; Barclay, E.; Wortham, N.; Pignatelli, M.; Freeman, A.; Pomplun, S.; Ellis, I.; et al. Adult leydig cell tumors of the testis caused by germline fumarate hydratase mutations. J. Clin. Endocrinol. Metab. 2006, 91, 3071-3075. [CrossRef]

42. Tomlinson, I.P.; Alam, N.A.; Rowan, A.J.; Barclay, E.; Jaeger, E.E.; Kelsell, D.; Leigh, I.; Gorman, P.; Lamlum, H.; Rahman, S.; et al. Germline mutations in $\mathrm{FH}$ predispose to dominantly inherited uterine fibroids, skin leiomyomata and papillary renal cell cancer. Nat. Genet. 2002, 30, 406-410. [CrossRef]

43. Isaacs, J.S.; Jung, Y.J.; Mole, D.R.; Lee, S.; Torres-Cabala, C.; Chung, Y.L.; Merino, M.; Trepel, J.; Zbar, B.; Toro, J.; et al. HIF overexpression correlates with biallelic loss of fumarate hydratase in renal cancer: Novel role of fumarate in regulation of HIF stability. Cancer Cell 2005, 8, 143-153. [CrossRef]

44. Frezza, C.; Zheng, L.; Folger, O.; Rajagopalan, K.N.; MacKenzie, E.D.; Jerby, L.; Micaroni, M.; Chaneton, B.; Adam, J.; Hedley, A.; et al. Haem oxygenase is synthetically lethal with the tumour suppressor fumarate hydratase. Nature 2011, 477, 225-228. [CrossRef]

45. Pollard, P.J.; Briere, J.J.; Alam, N.A.; Barwell, J.; Barclay, E.; Wortham, N.C.; Hunt, T.; Mitchell, M.; Olpin, S.; Moat, S.J.; et al. Accumulation of Krebs cycle intermediates and over-expression of HIF1alpha in tumours which result from germline FH and SDH mutations. Hum. Mol. Genet. 2005, 14, 2231-2239. [CrossRef]

46. Yang, M.; Su, H.; Soga, T.; Kranc, K.R.; Pollard, P.J. Prolyl hydroxylase domain enzymes: Important regulators of cancer metabolism. Hypoxia 2014, 2, 127-142. [CrossRef] [PubMed]

47. Pollard, P.J.; Wortham, N.C.; Tomlinson, I.P. The TCA cycle and tumorigenesis: The examples of fumarate hydratase and succinate dehydrogenase. Ann. Med. 2003, 35, 632-639. [CrossRef] [PubMed]

48. Bao, X.; Zhang, J.; Huang, G.; Yan, J.; Xu, C.; Dou, Z.; Sun, C.; Zhang, H. The crosstalk between HIFs and mitochondrial dysfunctions in cancer development. Cell Death Dis. 2021, 12, 215. [CrossRef]

49. Adam, J.; Yang, M.; Soga, T.; Pollard, P.J. Rare insights into cancer biology. Oncogene 2014, 33, 2547-2556. [CrossRef] [PubMed]

50. Ma, Q. Role of nrf2 in oxidative stress and toxicity. Annu. Rev. Pharmacol. Toxicol. 2013, 53, 401-426. [CrossRef] [PubMed]

51. Reyes, C.; Karamurzin, Y.; Frizzell, N.; Garg, K.; Nonaka, D.; Chen, Y.B.; Soslow, R.A. Uterine smooth muscle tumors with features suggesting fumarate hydratase aberration: Detailed morphologic analysis and correlation with S-(2-succino)-cysteine immunohistochemistry. Mod. Pathol. 2014, 27, 1020-1027. [CrossRef] [PubMed]

52. Heinonen, H.R.; Mehine, M.; Makinen, N.; Pasanen, A.; Pitkanen, E.; Karhu, A.; Sarvilinna, N.S.; Sjoberg, J.; Heikinheimo, O.; Butzow, R.; et al. Global metabolomic profiling of uterine leiomyomas. Br. J. Cancer 2017, 117, 1855-1864. [CrossRef]

53. Baysal, B.E.; Ferrell, R.E.; Willett-Brozick, J.E.; Lawrence, E.C.; Myssiorek, D.; Bosch, A.; van der Mey, A.; Taschner, P.E.; Rubinstein, W.S.; Myers, E.N.; et al. Mutations in SDHD, a mitochondrial complex II gene, in hereditary paraganglioma. Science 2000, 287, 848-851. [CrossRef] [PubMed]

54. Niemann, S.; Muller, U. Mutations in SDHC cause autosomal dominant paraganglioma, type 3. Nat. Genet. 2000, 26, 268-270. [CrossRef] [PubMed]

55. Burnichon, N.; Briere, J.J.; Libe, R.; Vescovo, L.; Riviere, J.; Tissier, F.; Jouanno, E.; Jeunemaitre, X.; Benit, P.; Tzagoloff, A.; et al. SDHA is a tumor suppressor gene causing paraganglioma. Hum. Mol. Genet. 2010, 19, 3011-3020. [CrossRef] [PubMed]

56. Astuti, D.; Latif, F.; Dallol, A.; Dahia, P.L.; Douglas, F.; George, E.; Skoldberg, F.; Husebye, E.S.; Eng, C.; Maher, E.R. Gene mutations in the succinate dehydrogenase subunit SDHB cause susceptibility to familial pheochromocytoma and to familial paraganglioma. Am. J. Hum. Genet. 2001, 69, 49-54. [CrossRef]

57. Hao, H.X.; Khalimonchuk, O.; Schraders, M.; Dephoure, N.; Bayley, J.P.; Kunst, H.; Devilee, P.; Cremers, C.W.; Schiffman, J.D.; Bentz, B.G.; et al. SDH5, a gene required for flavination of succinate dehydrogenase, is mutated in paraganglioma. Science 2009, 325, 1139-1142. [CrossRef]

58. Bayley, J.P.; Kunst, H.P.; Cascon, A.; Sampietro, M.L.; Gaal, J.; Korpershoek, E.; Hinojar-Gutierrez, A.; Timmers, H.J.; Hoefsloot, L.H.; Hermsen, M.A.; et al. SDHAF2 mutations in familial and sporadic paraganglioma and phaeochromocytoma. Lancet Oncol 2010, 11, 366-372. [CrossRef]

59. Szeto, S.S.; Reinke, S.N.; Sykes, B.D.; Lemire, B.D. Mutations in the Saccharomyces cerevisiae succinate dehydrogenase result in distinct metabolic phenotypes revealed through (1)H NMR-based metabolic footprinting. J. Proteome Res. 2010, 9, 6729-6739. [CrossRef] [PubMed]

60. Sjoblom, T.; Jones, S.; Wood, L.D.; Parsons, D.W.; Lin, J.; Barber, T.D.; Mandelker, D.; Leary, R.J.; Ptak, J.; Silliman, N.; et al. The consensus coding sequences of human breast and colorectal cancers. Science 2006, 314, 268-274. [CrossRef]

61. Parsons, D.W.; Jones, S.; Zhang, X.; Lin, J.C.; Leary, R.J.; Angenendt, P.; Mankoo, P.; Carter, H.; Siu, I.M.; Gallia, G.L.; et al. An integrated genomic analysis of human glioblastoma multiforme. Science 2008, 321, 1807-1812. [CrossRef]

62. Dang, L.; White, D.W.; Gross, S.; Bennett, B.D.; Bittinger, M.A.; Driggers, E.M.; Fantin, V.R.; Jang, H.G.; Jin, S.; Keenan, M.C.; et al. Cancer-associated IDH1 mutations produce 2-hydroxyglutarate. Nature 2009, 462, 739-744. [CrossRef] 
63. Mardis, E.R.; Ding, L.; Dooling, D.J.; Larson, D.E.; McLellan, M.D.; Chen, K.; Koboldt, D.C.; Fulton, R.S.; Delehaunty, K.D.; McGrath, S.D.; et al. Recurring mutations found by sequencing an acute myeloid leukemia genome. N. Engl. J. Med. 2009, 361, 1058-1066. [CrossRef]

64. Ward, P.S.; Patel, J.; Wise, D.R.; Abdel-Wahab, O.; Bennett, B.D.; Coller, H.A.; Cross, J.R.; Fantin, V.R.; Hedvat, C.V.; Perl, A.E.; et al. The common feature of leukemia-associated IDH1 and IDH2 mutations is a neomorphic enzyme activity converting alpha-ketoglutarate to 2-hydroxyglutarate. Cancer Cell 2010, 17, 225-234. [CrossRef]

65. Gross, S.; Cairns, R.A.; Minden, M.D.; Driggers, E.M.; Bittinger, M.A.; Jang, H.G.; Sasaki, M.; Jin, S.; Schenkein, D.P.; Su, S.M.; et al. Cancer-associated metabolite 2-hydroxyglutarate accumulates in acute myelogenous leukemia with isocitrate dehydrogenase 1 and 2 mutations. J. Exp. Med. 2010, 207, 339-344. [CrossRef]

66. Dvorak, A.; Zelenka, J.; Smolkova, K.; Vitek, L.; JeZek, P. Background levels of neomorphic 2-hydroxyglutarate facilitate proliferation of primary fibroblasts. Physiol Res. 2017, 66, 293-304. [CrossRef] [PubMed]

67. Frezza, C.; Pollard, P.J.; Gottlieb, E. Inborn and acquired metabolic defects in cancer. J. Mol. Med. 2011, 89, 213-220. [CrossRef] [PubMed]

68. Shim, E.H.; Livi, C.B.; Rakheja, D.; Tan, J.; Benson, D.; Parekh, V.; Kho, E.Y.; Ghosh, A.P.; Kirkman, R.; Velu, S.; et al. L-2Hydroxyglutarate: An epigenetic modifier and putative oncometabolite in renal cancer. Cancer Discov. 2014, 4, 1290-1298. [CrossRef] [PubMed]

69. Rzem, R.; Veiga-da-Cunha, M.; Noel, G.; Goffette, S.; Nassogne, M.C.; Tabarki, B.; Scholler, C.; Marquardt, T.; Vikkula, M.; Van Schaftingen, E. A gene encoding a putative FAD-dependent L-2-hydroxyglutarate dehydrogenase is mutated in L-2hydroxyglutaric aciduria. Proc. Natl. Acad. Sci. USA 2004, 101, 16849-16854. [CrossRef] [PubMed]

70. Rzem, R.; Vincent, M.F.; Van Schaftingen, E.; Veiga-da-Cunha, M. L-2-hydroxyglutaric aciduria, a defect of metabolite repair. J. Inherit. Metab. Dis. 2007, 30, 681-689. [CrossRef] [PubMed]

71. Oldham, W.M.; Clish, C.B.; Yang, Y.; Loscalzo, J. Hypoxia-Mediated Increases in L-2-hydroxyglutarate Coordinate the Metabolic Response to Reductive Stress. Cell Metab. 2015, 22, 291-303. [CrossRef] [PubMed]

72. Shim, H.; Dolde, C.; Lewis, B.C.; Wu, C.S.; Dang, G.; Jungmann, R.A.; Dalla-Favera, R.; Dang, C.V. c-Myc transactivation of LDH-A: Implications for tumor metabolism and growth. Proc. Natl. Acad. Sci. USA 1997, 94, 6658-6663. [CrossRef]

73. Intlekofer, A.M.; Dematteo, R.G.; Venneti, S.; Finley, L.W.; Lu, C.; Judkins, A.R.; Rustenburg, A.S.; Grinaway, P.B.; Chodera, J.D.; Cross, J.R.; et al. Hypoxia Induces Production of L-2-Hydroxyglutarate. Cell Metab. 2015, 22, 304-311. [CrossRef]

74. Sreekumar, A.; Poisson, L.M.; Rajendiran, T.M.; Khan, A.P.; Cao, Q.; Yu, J.; Laxman, B.; Mehra, R.; Lonigro, R.J.; Li, Y.; et al. Metabolomic profiles delineate potential role for sarcosine in prostate cancer progression. Nature 2009, 457, 910-914. [CrossRef] [PubMed]

75. Bianchi, F.; Dugheri, S.; Musci, M.; Bonacchi, A.; Salvadori, E.; Arcangeli, G.; Cupelli, V.; Lanciotti, M.; Masieri, L.; Serni, S.; et al. Fully automated solid-phase microextraction-fast gas chromatography-mass spectrometry method using a new ionic liquid column for high-throughput analysis of sarcosine and N-ethylglycine in human urine and urinary sediments. Anal. Chim. Acta 2011, 707, 197-203. [CrossRef] [PubMed]

76. Lucarelli, G.; Fanelli, M.; Larocca, A.M.; Germinario, C.A.; Rutigliano, M.; Vavallo, A.; Selvaggi, F.P.; Bettocchi, C.; Battaglia, M.; Ditonno, P. Serum sarcosine increases the accuracy of prostate cancer detection in patients with total serum PSA less than 4.0 ng/mL. Prostate 2012, 72, 1611-1621. [CrossRef] [PubMed]

77. Koutros, S.; Meyer, T.E.; Fox, S.D.; Issaq, H.J.; Veenstra, T.D.; Huang, W.Y.; Yu, K.; Albanes, D.; Chu, L.W.; Andriole, G.; et al. Prospective evaluation of serum sarcosine and risk of prostate cancer in the Prostate, Lung, Colorectal and Ovarian Cancer Screening Trial. Carcinogenesis 2013, 34, 2281-2285. [CrossRef] [PubMed]

78. Jentzmik, F.; Stephan, C.; Miller, K.; Schrader, M.; Erbersdobler, A.; Kristiansen, G.; Lein, M.; Jung, K. Sarcosine in urine after digital rectal examination fails as a marker in prostate cancer detection and identification of aggressive tumours. Eur. Urol. 2010, 58, 12-18; discussion 20-11. [CrossRef] [PubMed]

79. Jentzmik, F.; Stephan, C.; Lein, M.; Miller, K.; Kamlage, B.; Bethan, B.; Kristiansen, G.; Jung, K. Sarcosine in prostate cancer tissue is not a differential metabolite for prostate cancer aggressiveness and biochemical progression. J. Urol. 2011, 185, 706-711. [CrossRef]

80. Bohm, L.; Serafin, A.M.; Fernandez, P.; Van der Watt, G.; Bouic, P.J.; Harvey, J. Plasma sarcosine does not distinguish early and advanced stages of prostate cancer. S. Afr. Med. J. 2012, 102, 677-679. [CrossRef]

81. Struys, E.A.; Heijboer, A.C.; van Moorselaar, J.; Jakobs, C.; Blankenstein, M.A. Serum sarcosine is not a marker for prostate cancer. Ann. Clin. Biochem. 2010, 47, 282. [CrossRef]

82. Wu, H.; Liu, T.; Ma, C.; Xue, R.; Deng, C.; Zeng, H.; Shen, X. GC/MS-based metabolomic approach to validate the role of urinary sarcosine and target biomarkers for human prostate cancer by microwave-assisted derivatization. Anal. Bioanal. Chem. 2011, 401, 635-646. [CrossRef] [PubMed]

83. Cao, D.L.; Ye, D.W.; Zhu, Y.; Zhang, H.L.; Wang, Y.X.; Yao, X.D. Efforts to resolve the contradictions in early diagnosis of prostate cancer: A comparison of different algorithms of sarcosine in urine. Prostate Cancer Prostatic. Dis. 2011, 14, 166-172. [CrossRef]

84. de Vogel, S.; Ulvik, A.; Meyer, K.; Ueland, P.M.; Nygard, O.; Vollset, S.E.; Tell, G.S.; Gregory, J.F., 3rd; Tretli, S.; Bjorge, T. Sarcosine and other metabolites along the choline oxidation pathway in relation to prostate cancer-a large nested case-control study within the JANUS cohort in Norway. Int. J. Cancer 2014, 134, 197-206. [CrossRef] [PubMed] 
85. Markin, P.A.; Brito, A.; Moskaleva, N.; Fodor, M.; Lartsova, E.V.; Shpot, Y.V.; Lerner, Y.V.; Mikhajlov, V.Y.; Potoldykova, N.V.; Enikeev, D.V.; et al. Plasma Sarcosine Measured by Gas Chromatography-Mass Spectrometry Distinguishes Prostatic Intraepithelial Neoplasia and Prostate Cancer from Benign Prostate Hyperplasia. Lab. Med. 2020, 51, 566-573. [CrossRef]

86. Strmiska, V.; Michalek, P.; Eckschlager, T.; Stiborova, M.; Adam, V.; Krizkova, S.; Heger, Z. Prostate cancer-specific hallmarks of amino acids metabolism: Towards a paradigm of precision medicine. Biochim. Biophys. Acta Rev. Cancer 2019, 1871, $248-258$. [CrossRef] [PubMed]

87. Strmiska, V.; Michalek, P.; Lackova, Z.; Guran, R.; Krizkova, S.; Vanickova, L.; Zitka, O.; Stiborova, M.; Eckschlager, T.; Klejdus, B.; et al. Sarcosine is a prostate epigenetic modifier that elicits aberrant methylation patterns through the SAMe-Dnmts axis. Mol. Oncol. 2019, 13, 1002-1017. [CrossRef] [PubMed]

88. Jain, M.; Nilsson, R.; Sharma, S.; Madhusudhan, N.; Kitami, T.; Souza, A.L.; Kafri, R.; Kirschner, M.W.; Clish, C.B.; Mootha, V.K. Metabolite profiling identifies a key role for glycine in rapid cancer cell proliferation. Science 2012, 336, 1040-1044. [CrossRef]

89. Sniegowski, T.; Korac, K.; Bhutia, Y.D.; Ganapathy, V. SLC6A14 and SLC38A5 Drive the Glutaminolysis and Serine-Glycine-OneCarbon Pathways in Cancer. Pharmaceuticals 2021, 14, 216. [CrossRef]

90. Yoo, H.C.; Yu, Y.C.; Sung, Y.; Han, J.M. Glutamine reliance in cell metabolism. Exp. Mol. Med. 2020, 52, 1496-1516. [CrossRef]

91. Zhang, W.C.; Shyh-Chang, N.; Yang, H.; Rai, A.; Umashankar, S.; Ma, S.; Soh, B.S.; Sun, L.L.; Tai, B.C.; Nga, M.E.; et al. Glycine decarboxylase activity drives non-small cell lung cancer tumor-initiating cells and tumorigenesis. Cell 2012, 148, $259-272$. [CrossRef]

92. Gao, P.; Yang, C.; Nesvick, C.L.; Feldman, M.J.; Sizdahkhani, S.; Liu, H.; Chu, H.; Yang, F.; Tang, L.; Tian, J.; et al. Hypotaurine evokes a malignant phenotype in glioma through aberrant hypoxic signaling. Oncotarget 2016, 7, 15200-15214. [CrossRef]

93. Chinnaiyan, P.; Kensicki, E.; Bloom, G.; Prabhu, A.; Sarcar, B.; Kahali, S.; Eschrich, S.; Qu, X.; Forsyth, P.; Gillies, R. The metabolomic signature of malignant glioma reflects accelerated anabolic metabolism. Cancer Res. 2012, 72, 5878-5888. [CrossRef]

94. Prabhu, A.; Sarcar, B.; Kahali, S.; Yuan, Z.; Johnson, J.J.; Adam, K.P.; Kensicki, E.; Chinnaiyan, P. Cysteine catabolism: A novel metabolic pathway contributing to glioblastoma growth. Cancer Res. 2014, 74, 787-796. [CrossRef]

95. Ueki, I.; Stipanuk, M.H. 3T3-L1 adipocytes and rat adipose tissue have a high capacity for taurine synthesis by the cysteine dioxygenase/cysteinesulfinate decarboxylase and cysteamine dioxygenase pathways. J. Nutr 2009, 139, 207-214. [CrossRef] [PubMed]

96. Shen, D.; Tian, L.; Yang, F.; Li, J.; Li, X.; Yao, Y.; Lam, E.W.; Gao, P.; Jin, B.; Wang, R. ADO/hypotaurine: A novel metabolic pathway contributing to glioblastoma development. Cell Death Discov. 2021, 7, 21. [CrossRef]

97. Ippolito, L.; Morandi, A.; Giannoni, E.; Chiarugi, P. Lactate: A Metabolic Driver in the Tumour Landscape. Trends Biochem. Sci. 2019, 44, 153-166. [CrossRef]

98. Pereira-Nunes, A.; Afonso, J.; Granja, S.; Baltazar, F. Lactate and Lactate Transporters as Key Players in the Maintenance of the Warburg Effect. Adv. Exp. Med. Biol. 2020, 1219, 51-74. [CrossRef]

99. Brooks, G.A. The lactate shuttle during exercise and recovery. Med. Sci. Sports Exerc. 1986, 18, 360-368. [CrossRef] [PubMed]

100. Brooks, G.A. Lactate production under fully aerobic conditions: The lactate shuttle during rest and exercise. Fed. Proc. 1986, 45, 2924-2929. [PubMed]

101. Baltazar, F.; Afonso, J.; Costa, M.; Granja, S. Lactate Beyond a Waste Metabolite: Metabolic Affairs and Signaling in Malignancy. Front. Oncol. 2020, 10, 231. [CrossRef] [PubMed]

102. Chen, P.; Zuo, H.; Xiong, H.; Kolar, M.J.; Chu, Q.; Saghatelian, A.; Siegwart, D.J.; Wan, Y. Gpr132 sensing of lactate mediates tumor-macrophage interplay to promote breast cancer metastasis. Proc. Natl. Acad. Sci. USA 2017, 114, 580-585. [CrossRef] [PubMed]

103. de Goede, K.E.; Driessen, A.J.M.; Van den Bossche, J. Metabolic Cancer-Macrophage Crosstalk in the Tumor Microenvironment. Biology 2020, 9, 380. [CrossRef] [PubMed]

104. Emir, U.E.; Larkin, S.J.; de Pennington, N.; Voets, N.; Plaha, P.; Stacey, R.; Al-Qahtani, K.; McCullagh, J.; Schofield, C.J.; Clare, S.; et al. Noninvasive Quantification of 2-Hydroxyglutarate in Human Gliomas with IDH1 and IDH2 Mutations. Cancer Res. 2016, 76, 43-49. [CrossRef] [PubMed]

105. Wishart, D.S.; Mandal, R.; Stanislaus, A.; Ramirez-Gaona, M. Cancer Metabolomics and the Human Metabolome Database. Metabolites 2016, 6, 10. [CrossRef] [PubMed]

106. Khatami, F.; Payab, M.; Sarvari, M.; Gilany, K.; Larijani, B.; Arjmand, B.; Tavangar, S.M. Oncometabolites as biomarkers in thyroid cancer: A systematic review. Cancer Manag. Res. 2019, 11, 1829-1841. [CrossRef]

107. Miccoli, P.; Torregrossa, L.; Shintu, L.; Magalhaes, A.; Chandran, J.; Tintaru, A.; Ugolini, C.; Minuto, M.N.; Miccoli, M.; Basolo, F.; et al. Metabolomics approach to thyroid nodules: A high-resolution magic-angle spinning nuclear magnetic resonance-based study. Surgery 2012, 152, 1118-1124. [CrossRef]

108. Tessem, M.B.; Swanson, M.G.; Keshari, K.R.; Albers, M.J.; Joun, D.; Tabatabai, Z.L.; Simko, J.P.; Shinohara, K.; Nelson, S.J.; Vigneron, D.B.; et al. Evaluation of lactate and alanine as metabolic biomarkers of prostate cancer using $1 \mathrm{H}$ HR-MAS spectroscopy of biopsy tissues. Magn. Reson. Med. 2008, 60, 510-516. [CrossRef]

109. Beadle, G.W.; Mitchell, H.K.; Nyc, J.F. Kynurenine as an Intermediate in the Formation of Nicotinic Acid from Tryptophane by Neurospora. Proc. Natl. Acad. Sci. USA 1947, 33, 155-158. [CrossRef] [PubMed] 
110. Venkateswaran, N.; Lafita-Navarro, M.C.; Hao, Y.H.; Kilgore, J.A.; Perez-Castro, L.; Braverman, J.; Borenstein-Auerbach, N.; Kim, M.; Lesner, N.P.; Mishra, P.; et al. MYC promotes tryptophan uptake and metabolism by the kynurenine pathway in colon cancer. Genes Dev. 2019, 33, 1236-1251. [CrossRef]

111. Venkateswaran, N.; Conacci-Sorrell, M. Kynurenine: An oncometabolite in colon cancer. Cell Stress 2020, 4, 24-26. [CrossRef]

112. Yang, Y.; Sauve, A.A. NAD(+) metabolism: Bioenergetics, signaling and manipulation for therapy. Biochim. Biophys. Acta 2016, 1864, 1787-1800. [CrossRef]

113. Rather, G.M.; Pramono, A.A.; Szekely, Z.; Bertino, J.R.; Tedeschi, P.M. In cancer, all roads lead to NADPH. Pharmacol. Ther. 2021, 226, 107864. [CrossRef] [PubMed]

114. Lin, J.A.; Wu, C.H.; Lu, C.C.; Hsia, S.M.; Yen, G.C. Glycative stress from advanced glycation end products (AGEs) and dicarbonyls: An emerging biological factor in cancer onset and progression. Mol. Nutr. Food Res. 2016, 60, 1850-1864. [CrossRef]

115. Wilker, S.C.; Chellan, P.; Arnold, B.M.; Nagaraj, R.H. Chromatographic quantification of argpyrimidine, a methylglyoxal-derived product in tissue proteins: Comparison with pentosidine. Anal. Biochem. 2001, 290, 353-358. [CrossRef] [PubMed]

116. Rabbani, N.; Ashour, A.; Thornalley, P.J. Mass spectrometric determination of early and advanced glycation in biology. Glycoconj. J. 2016, 33, 553-568. [CrossRef] [PubMed]

117. Bellier, J.; Nokin, M.J.; Larde, E.; Karoyan, P.; Peulen, O.; Castronovo, V.; Bellahcene, A. Methylglyoxal, a potent inducer of AGEs, connects between diabetes and cancer. Diabetes Res. Clin. Pract 2019, 148, 200-211. [CrossRef] [PubMed]

118. Leone, A.; Nigro, C.; Nicolo, A.; Prevenzano, I.; Formisano, P.; Beguinot, F.; Miele, C. The Dual-Role of Methylglyoxal in Tumor Progression-Novel Therapeutic Approaches. Front. Oncol 2021, 11, 645686. [CrossRef]

119. Koo, J.H.; Guan, K.L. Interplay between YAP/TAZ and Metabolism. Cell Metab. 2018, 28, 196-206. [CrossRef]

120. Wang, Z.; Yuan, Y.; Ji, X.; Xia, X.; Li, Z.; Yi, X.; Zhu, Y.; Guo, T.; Wang, Y.; Chen, L.; et al. The Hippo-TAZ axis mediates vascular endothelial growth factor $\mathrm{C}$ in glioblastoma-derived exosomes to promote angiogenesis. Cancer Lett. 2021. [CrossRef]

121. Nokin, M.J.; Durieux, F.; Peixoto, P.; Chiavarina, B.; Peulen, O.; Blomme, A.; Turtoi, A.; Costanza, B.; Smargiasso, N.; Baiwir, D.; et al. Methylglyoxal, a glycolysis side-product, induces Hsp90 glycation and YAP-mediated tumor growth and metastasis. eLife 2016, 5. [CrossRef]

122. Roci, I.; Watrous, J.D.; Lagerborg, K.A.; Jain, M.; Nilsson, R. Mapping metabolic oscillations during cell cycle progression. Cell Cycle 2020, 19, 2676-2684. [CrossRef]

123. Kani, S.; Nakayama, E.; Yoda, A.; Onishi, N.; Sougawa, N.; Hazaka, Y.; Umeda, T.; Takeda, K.; Ichijo, H.; Hamada, Y.; et al. Chk2 kinase is required for methylglyoxal-induced G2/M cell-cycle checkpoint arrest: Implication of cell-cycle checkpoint regulation in diabetic oxidative stress signaling. Genes Cells 2007, 12, 919-928. [CrossRef] [PubMed]

124. Bultman, S.J. Interplay between diet, gut microbiota, epigenetic events, and colorectal cancer. Mol. Nutr. Food Res. $2017,61$. [CrossRef]

125. San-Millan, I.; Julian, C.G.; Matarazzo, C.; Martinez, J.; Brooks, G.A. Is Lactate an Oncometabolite? Evidence Supporting a Role for Lactate in the Regulation of Transcriptional Activity of Cancer-Related Genes in MCF7 Breast Cancer Cells. Front. Oncol. 2019, 9, 1536. [CrossRef] [PubMed]

126. Comito, G.; Iscaro, A.; Bacci, M.; Morandi, A.; Ippolito, L.; Parri, M.; Montagnani, I.; Raspollini, M.R.; Serni, S.; Simeoni, L.; et al. Lactate modulates CD4(+) T-cell polarization and induces an immunosuppressive environment, which sustains prostate carcinoma progression via TLR8/miR21 axis. Oncogene 2019, 38, 3681-3695. [CrossRef]

127. Bellier, J.; Nokin, M.J.; Caprasse, M.; Tiamiou, A.; Blomme, A.; Scheijen, J.L.; Koopmansch, B.; MacKay, G.M.; Chiavarina, B.; Costanza, B.; et al. Methylglyoxal Scavengers Resensitize KRAS-Mutated Colorectal Tumors to Cetuximab. Cell Rep. 2020, 30, 1400-1416 e1046. [CrossRef]

128. Dang, L.; Jin, S.; Su, S.M. IDH mutations in glioma and acute myeloid leukemia. Trends Mol. Med. 2010, 16, 387-397. [CrossRef] [PubMed]

129. Yen, K.; Travins, J.; Wang, F.; David, M.D.; Artin, E.; Straley, K.; Padyana, A.; Gross, S.; DeLaBarre, B.; Tobin, E.; et al. AG-221, a First-in-Class Therapy Targeting Acute Myeloid Leukemia Harboring Oncogenic IDH2 Mutations. Cancer Discov. 2017, 7, 478-493. [CrossRef] [PubMed]

130. Mullard, A. Cancer metabolism pipeline breaks new ground. Nat. Rev. Drug Discov. 2016, 15, 735-737. [CrossRef] [PubMed]

131. Rai, S.K.; Bril, F.; Hatch, H.M.; Xu, Y.; Shelton, L.; Kalavalapalli, S.; Click, A.; Lee, D.; Beecher, C.; Kirby, A.; et al. Targeting pheochromocytoma/paraganglioma with polyamine inhibitors. Metabolism 2020, 110, 154297. [CrossRef] 